

\section{RESULTS AND ANALYSIS}

The traffic accident situation in kolkata as well as in India is really alarming. The incidence of accidental deaths has shown an increasing trend during the period $2007-2012$ with an increase of $39.17 \%$ in the year 2012.It has total 6779 accidental cases among which 471 are fatalities, 1608 injuries and 872 non injuries.

\section{CAUSES OF ACCIDENTS}

The main causes of the road accidents are poor condition of vehicles ,bad geometrics of road, driving impairment, aggressiveness of the drivers, crossing the road ignoring zebra crossing, and narrow road space with huge traffic volume and foggy condition during winter.

\section{TREND OF ROAD ACCIDENTS}

The accidental prone roads of three years i.e 2011,2012 and 2013 has been compared where it is seen that APC road, D.H road, Taratala road, Central avenue, M.G road are common which indicates that these roads are more accident prone roads than other roads in kolkata. The trend line showing the trend of accidents for the successive years of 2007 to 2014.however the trend of curve is upward rising to 2014.Therefore certain measures are needed to be taken to slow down the accidental rates.

\section{CHART 1.1 THE TREND OF ACCIDENTS}

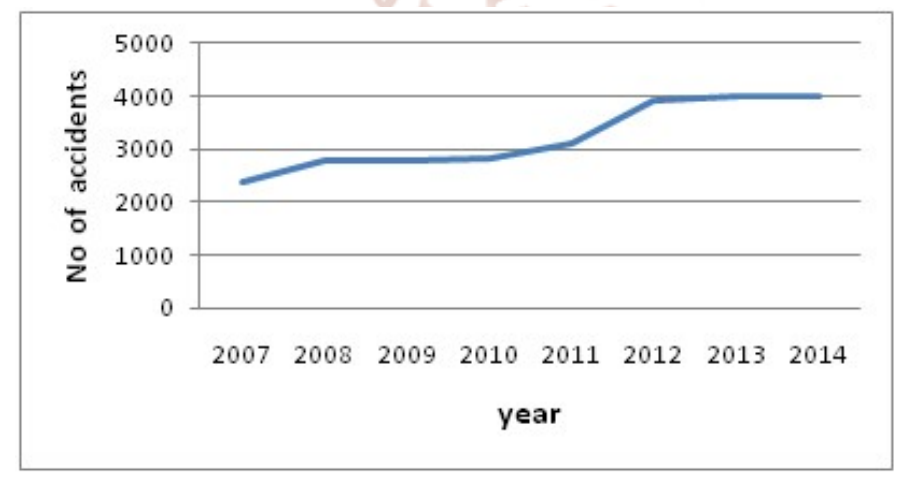

Source kolkata traffic police

\section{GENDER WISE ACCIDENTS}

The analysis of accident deaths in last 10years in kolkata shows greater vulnerability of male towards accidents which are probably due to greater exposure of males to the outside world of greatest workforce participation. the females, mainly confined to the household activities, are less affected but with their increasing workforce participation the trend is on increase.
AGE FACTORS IN ACCIDENTAL DEATHS Age factor plays a crucial role in this context. In a recent survey conducted by the kolkata traffic police all over, spanning over 2012-2013, about 450-500people in 18-30 age groups die in road accidents accounting for $40-50 \%$ of total accidents every year. Number of children in 5-10 years age group who succumb to road accident annually is about $10 \%$,most being street children. It is said the next highly vulnerable age group which comes just after the age group of 18 years to 30 years is above 50 years. Weak eye sight, poor reflex, mental pressure and anxiety are the main caused for this accident.

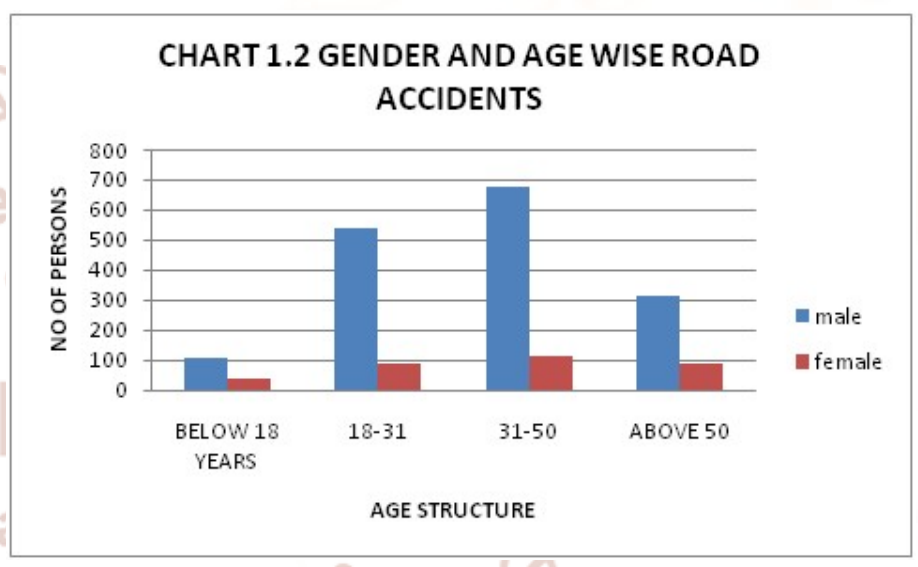

Source: kolkata traffic police

\section{HOURLY DISTRIBUTION OF ACCIDENT}

Here it is being tried to find out the dangerous time during a day that are very highly vulnerable to different type of accident. There are mainly three type of accident being taken under consideration, these are Fatal, Serious injury, Simple injury or minor injury. In this purpose a full day has been divided into several parts. From the following table in can be said that, the dangerous time zone for accidents are 9 A.M to 12 P.M and 6 P.M to 10 P.M. As within this time slot the working populations and students are generally remain very high on road because the time slot from 9 A.M. to 12 P.M. is the time when they go to their working places and institutions and within the time slot from $1 \mathrm{pm}$ to $5 \mathrm{pm}$, they use to back to home. Nearly $80-90 \%$ of all accident cases occur during this part of the day. Notably more accidents occur beyond traffic hours probably due to lack of traffic control, increase movement of heavy goods vehicle high speed and the drunk condition of the driver.

\section{MONTH WISE ACCIDENT}

There is a growing numbers of accidents in kolkata from October to November and the reason lies in heavy influxes of tourists from outside the city specially from rural area during this winter month to 
visit zoo, Victoria memorial.museum etc. and also for various festivals celebrated during this time. Another causes of accidents during winter is heavy fog. The rainy month of July and august record accidents on account of the roads becoming slippery.

Table 1.1

\begin{tabular}{|c|c|c|}
\hline \multicolumn{3}{|c|}{ MONTH WISE ACCIDENT PATTERN } \\
\hline $\begin{array}{c}\text { NAME OF THE } \\
\text { MONTH }\end{array}$ & FATAL & $\begin{array}{c}\text { NON } \\
\text { FATAL }\end{array}$ \\
\hline JANUARY & 47 & 240 \\
\hline FEBRUARY & 42 & 223 \\
\hline MARCH & 34 & 233 \\
\hline APRIL & 37 & 223 \\
\hline MAY & 46 & 285 \\
\hline JUNE & 38 & 323 \\
\hline JULY & 45 & 282 \\
\hline AUGUST & 38 & 232 \\
\hline SEPTEMBER & 39 & 250 \\
\hline OCTOBER & 49 & 297 \\
\hline NOVEMBER & 49 & 288 \\
\hline DECEMBER & 34 & 340 \\
\hline
\end{tabular}

Source; kolkata traffic police

\section{PEDESTRIAN DEATH AND INJURE TYPE}

Motorized vehicles accounted for 95.5 per cent of the total road accidents during the calendar year 2014 . Amongst the vehicle categories, two-wheelers accounted for the highest share in total road accidents (28.8 per cent) in 2014 followed by cars, jeeps and taxis (23.6 per cent); trucks, tempos, tractors and other articulated vehicles (19.7 per cent), Other motor vehicles (9.0 per cent), buses ( 8.3 per cent) and AutoRickshaws (6.1 per cent). Share of two wheelers in total road accidents has increased continuously from 26.3 per cent in 2013 to 27.3 per cent in 2014 . Next to two wheelers, share of cars, jeeps and taxis has also gone up slightly from 22.2 per cent in 2013 to 22.7 per cent. The no of pedestrians injured by car is comparatively higher than any other vehicles

\section{VEHICLE WISE NO OF ACCIDENT}

The number of accident's is varies with the different types of vehicle. The pie diagram shows the number of death and injured persons by different vehicles. From this diagram it can be said that the number of accident by motor cyclist is maximum. One of the main cause of this accident's is lack of awareness of people. many times they do not use helmet. Motorized vehicles accounted for 95.5 per cent of the total road accidents during the calendar year 2014. Amongst the vehicle categories, two-wheelers accounted for the highest share in total road accidents (38.8 per cent) in 2014 followed by cars, jeeps and taxis ,trucks, tempos, and other articulated vehicles (19.7 per cent), Other motor vehicles (9.0 per cent), buses (28.3 per cent) . Share of two wheelers in total road accidents has increased continuously from 26.3 per cent in 2012 to 27.3 per cent in 2013 and 28.8 per cent in 2014 . Next to two wheelers, share of cars, jeeps and taxis has also gone up slightly from 22.2 per cent in 2012 to 22.7 per cent in 2013 and 23.6 per cent in 2014.

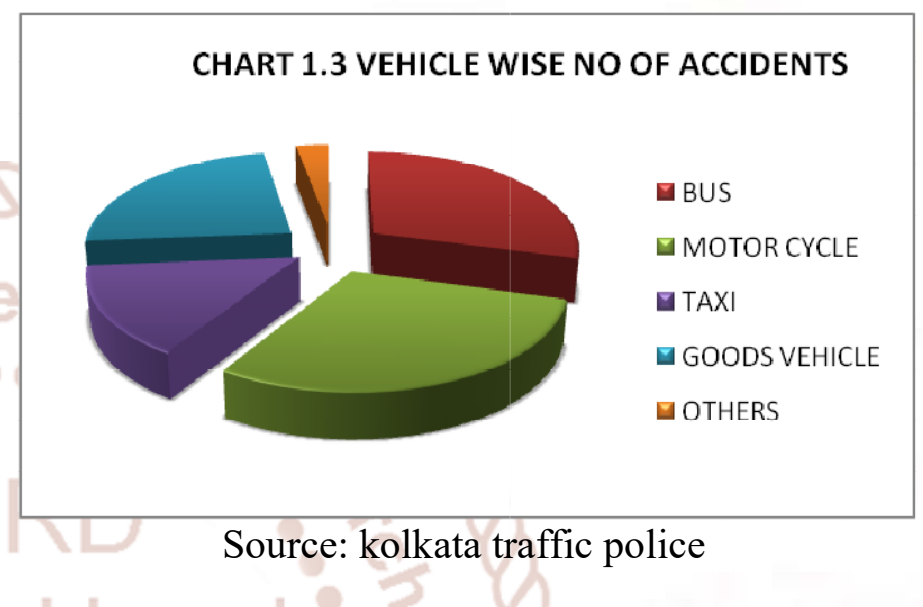

\section{CORRECTIVE MEASURES}

Accidents can be fatal or non fatal, but the mental and emotional impact of an accident are deeper than physical damage.

A lot of corrective measures have been adopt by the government of West bengal kolkata municipal corporation and the traffic police department which can be discussed under to broad heads.

\section{- PENALTIES AND PUNISHMENT}

A study reveals that drivers, riders pedestrians accounts for more than half of the traffic death occurring every year specially for ignoring traffic rules. Some of the punishments here:

Kolkata police have recently launched a drive to find pedestrians crossing roads with out using zebra crossing and traffic signals. rupeese 50 will be fined for crossing road without using zebra crossing and traffic signals at different road junction.

Leaving vehicles in a position that may cause danger obstruction to any road user are prosecuted under U/S122/177MVA.

Violation of signals and taking $U$ turn are considered serious offence and are fineable. 
IMPLEMENTING TOOLS OF SAFETY

Modern policing is critically dependent on technology because safety of citizens is the prime concern.

Table 1.2

\begin{tabular}{|c|c|}
\hline EQUIPMIENTS & QUANTITY \\
\hline CCTV CAMERA & 36 \\
\hline TRAFFIC LIGHT SIGNAL & 403 \\
\hline BREATH ANALYSER MACHINE & 50 \\
\hline OXYGEN CONCENTRATOR & 11 \\
\hline DIGITAL CAMERA & 28 \\
\hline HANDYCAM CAMERA & 24 \\
\hline LOUD HAILER & 82 \\
\hline SPEED RADER GUN & 15 \\
\hline GAS ANALYSER(SMOKE TEST) & 10 \\
\hline
\end{tabular}

Source: kolkata traffic police

\section{TOOLS OF TECHNOLOGY}

$>$ Speed rader gun are used to detect the over speeding vehicles.

$>$ C.C TV's are installed at strategic locations to monitor traffic flow centrally from Lal Bazar traffic control room.

$>$ Breath analyzer are used to detect drunken driving.

$>$ All the traffics guards are connected with central server through virtual private network system which helps to maintain traffic data in scientific manner.

$>$ Traffics alerts in case of congestion/diversion through sms system is provided to common people

$>$ Social networking system like facebook and twitter are becoming more popular day by day.

\section{CONCLUSION}

With the increase in population and various socioeconomic functions, volume of traffic is increasing at tremendous rate. Kolkata city with its majority of roads having a north-south alignment has its major accident prone area aligned in the same direction.

\section{- Some recommendation for city traffic}

The five members traffic committee, set up by Calcutta high court submitted its report to the division bench. The committee, which surveyed the strand road, bra bourn road, chitpur road, M.G road and kalakar street has recommended the following measures:
$>$ No shop owner should be allowed to stack goods on the pavement.

$>$ No structure should be allowed on the pavement.

$>$ No vehicle should be parked besides the pavement for loading and unloading purposes during office hours.

$>$ No hand-rickshaw should be allowed to be parked on the pavements.

$>$ There should be a railing along the pavement to prevent pedestrians from walking on the carriage way.

$>$ On the one way roads, parking should be allowed only on one side leaving at least fifty feet from the crossing.

\section{- Strategies for development}

State government has adopted a policy of dispersal of metropolitan activity to evolve a decentralised spatial structure. To achieve this two actions have been taken-

A. To develop small and medium towns and growth centres in the state outside kolkata metropolitan area(KMA).

B. To develop municipal town as well as new settlement with in KMA but outside metro.

Existing wholesale trade in Burrabazar should be gradually relocated outside metro.

There is need for engineering, assessing and improving accident prone stretches.

\section{- GOLDEN RULES FOR THE ROAD}

The kolkata traffic police, in its annual review report for the year 2013,suggested some certain rules for safe movement and journey.

\section{A. Pedestrians}

1. Always walk on the foot path,they are meant for you.

2. Cross roads where there are pedestrian crossing.

3. Even kerb be drill and also teach children. The five golden rules of kerb drill are- STOP AT THE KERB/LOOK RIGHT/LOOK LEFT/LOOK RIGHT AGAIN

4. If the road is clear walk straight across,dont run.

B. Before driving make sure that

1. Your vehicles is registered.

2. You have a valid driving license.

3. You are not under influence of drinks/drugs

4. You were wearing a helmet if driving a twowheeler. 
C. While on move:-

1. Know your route and choose the correct lane.

2. Keep foot off the clutch and drive in correct gear.

3. Always keep both hands on the steering wheel

4. Never turned around to talk to another passengers or allow your attention to be diverted

5. Never race on public roads.

6. Never exceed the speed limits

7. Never switch off the engine while stopping at a traffic signal.

Added to this is the need to raise awarness on the part of individual citizen and administration for becoming alert of their respective roles in maintain a system capable of ensuring adequate safety.

\section{BIBLIOGRAPHY:-}

1. Suman Paul, 2012 Research Scholars Library: Archives of Applied Science Research, 4 (3):1376-1388.

2. Suman Paul and Kanan Chatterjee, 2012 Archives of Applied Science Research, 4 (5): 2052-2067.

3. Tarko, Andrzej P. Tarko, Kumares C. Sinha, and Omer Farooq. 1997 "Methodology for Identifying Highway Safety Problem Areas", Transportation Research Record No. 1542 Safety and Human Performance/Statistical Methods and Accident Analysis for Highway and Traffic Safety, Transportation Research Board/National Research Council, National Academy Press, Washington, D.C., 49-53.

4. Experimental Plans for Accident Studies of Highway Design Elements: Encroachment Accident Study, 1997, Publication No. FHWARD-96-081, U.S. Department of Transportation/Federal Highway Administration/Research and Development, Turner-Fairbank Highway Research Center, McLean, VA, January, p. 112.

5. Gattis, J.L., M.S. Alguire, and S.R.K. Naria. 1996 Journal of Transportation Engineering, American Society of Civil Engineers, 122 (3), 210-214.

6. Valli, P. and P.K. Sarkar, 1997. Models for road accidents in India, Highway Research Bulletin, vol. 56, pp. 1-11 (New Delhi, Indian Road Congress).

7. Sing S.K., and A. Misra, 2001. Road accident analysis: a case study of Patna, Urban Transport Journal, pp. 60-75.
8. Smeed, R.J., 1972. The usefulness of formula in traffic engineering and road safety, Accident Analysis and Preview, vol. 4, pp. 303-312.

9. Srinivasan, N, and K. Prasad, 1979. Fatal accident rates in Delhi, Indian Highways, vol. 4, No.3.

ANNEXURE:

Table 1.1 The trends of no of accidents(2007-2014)

\begin{tabular}{|c|l|}
\hline year & \multicolumn{1}{|c|}{ no of accident } \\
\hline 2007 & 2396 \\
\hline 2008 & 2812 \\
\hline 2009 & 2789 \\
\hline 2010 & 2843 \\
\hline 2011 & 3133 \\
\hline 2012 & 3937 \\
\hline 2013 & 3999 \\
\hline 2014 & 4017 \\
\hline
\end{tabular}

\section{Source-kolkata traffic police}

Table 1.2 Gender and age wise accident pattern

\begin{tabular}{|l|l|l|}
\hline AGE STRUCTURE & \multicolumn{2}{|c|}{$\begin{array}{c}\text { NO OF } \\
\text { INJURY } \\
\text { male }\end{array}$} \\
\hline BELOW18 YEARS & 104 & 37 \\
\hline $18-31$ & 537 & 90 \\
\hline $31-50$ & 673 & 115 \\
\hline ABOVE 50 & 312 & 86 \\
\hline
\end{tabular}

\section{Source-kolkata traffic police}

Table 1.3 Vehicle wise accident pattern

\section{\begin{tabular}{|l|l|} 
Types of vehicle & no of death and injury
\end{tabular}}

\begin{tabular}{|l|l|}
\hline BUS & 564 \\
\hline MOTOR CYCLE & 278 \\
\hline TAXI & 284 \\
\hline GOODS VEHICLE & 452 \\
\hline OTHERS & 56 \\
\hline
\end{tabular}

Source-kolkata traffic police 